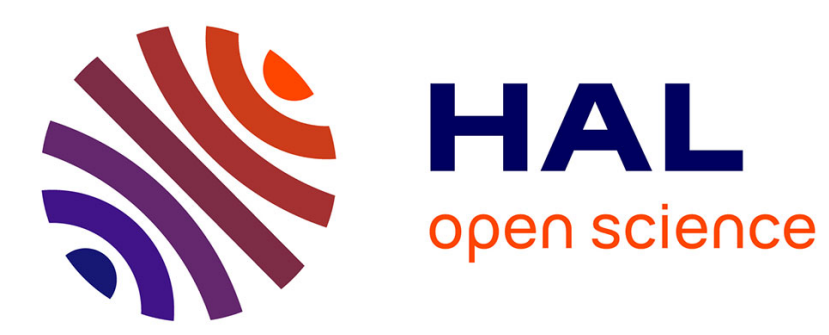

\title{
ISOTOPE EFFECTS IN SUPERCONDUCTING TRANSITION METAL HYDRIDES
}

\author{
J. Hauck
}

\section{To cite this version:}

J. Hauck. ISOTOPE EFFECTS IN SUPERCONDUCTING TRANSITION METAL HYDRIDES. Journal de Physique Colloques, 1978, 39 (C6), pp.C6-426-C6-427. 10.1051/jphyscol:19786191 . jpa00217608

\section{HAL Id: jpa-00217608 https://hal.science/jpa-00217608}

Submitted on 1 Jan 1978

HAL is a multi-disciplinary open access archive for the deposit and dissemination of scientific research documents, whether they are published or not. The documents may come from teaching and research institutions in France or abroad, or from public or private research centers.
L'archive ouverte pluridisciplinaire HAL, est destinée au dépôt et à la diffusion de documents scientifiques de niveau recherche, publiés ou non, émanant des établissements d'enseignement et de recherche français ou étrangers, des laboratoires publics ou privés. 


\section{ISOTOPE EFFECTS IN SUPERCONDUCTING TRANSITION METAL HYDRIDES}

J. Hauck

Fronziskusstr. 20, D-517 Jülich, FRG.

Résumé.- Les effets isotopiques, normal et inverse, dans les hydrures supraconducteurs de métaux de transition dépendent des différentes énergies de champ cristallin. $\mathrm{VH}_{2}$ devient supraconducteur audessous de $3,9 \mathrm{~K}$.

Abstract. - The normal and reverse isotope effects of superconducting transition metal hydrides depend on the different crystal field energies. $\mathrm{VH}_{2}$ gets superconducting below $3.9 \mathrm{~K}$.

Since the discovery of superconducting in $\mathrm{Th}_{4} \mathrm{H}_{15} / 1 /$ and $\mathrm{PdH} / 2 /$ in 1970 and 1972, resp. many metal-hydrogen systems were investigated with the aim for a better understanding of superconductivity in such simple compounds where $H$ enters interstitial sites without major changes of the metal lattice structure but some variation of the average number of valence electrons per atom (e/a) with $H$ content. The basic structure types of transition metal hydrides with bc or fcc metal lattices are shown in figure 1. In the slightly distorted bc or in the fcc metal lattice the $\mathrm{H}$ atoms can occupy tetrahedral or octahedral interstices which can be correlated by the translations $T\left(\frac{1}{4} \circ 0\right)$ or $\left(\frac{1}{4} \frac{1}{4} \frac{1}{4}\right)$, resp. The lattice energies' of such closely related structures show only small differences which can be gained by crystal field energy depending on the state of the $\mathrm{H}$ atoms/3/. $\mathrm{H}^{\delta+}$ enters octahedral sites with a relatively high electron density, $\mathrm{H}^{\delta-}$ is repelled to tetrahedral sites. The Coulomb energy contributions of the crystal field stabilization and of the Madelung lattice energy have a minimum for $\mathrm{V}$ hydrides and increase as $\left|\delta^{+}\right|$or $\left|\delta^{-}\right|$increases with the difference in electronegativity (or electron work function/5/) of the metal/4/ (figure 2). With increasing temperature, increasing $\mathrm{H}$ concentration, or by exchange of $\mathrm{H}$ by $\mathrm{D}$ the effective positive charge at the $\mathrm{H}$ atoms decreases and/ox the electron concentration nearby the $D$ atoms increases because of the smaller thermal motion. Both lead to the same effect as a smaller electronegativity of the metal (figure 2) $/ 4 /$.

Several other properties of the hydrides can be correlated to the coulomb energy/4/. The force constant of the $\mathrm{M}-\mathrm{H}$ bond is small if the Coulomb interactions between $M$ and $H$ are small. In that case the mean square amplitude of $\mathrm{H}$ oscillation beco-

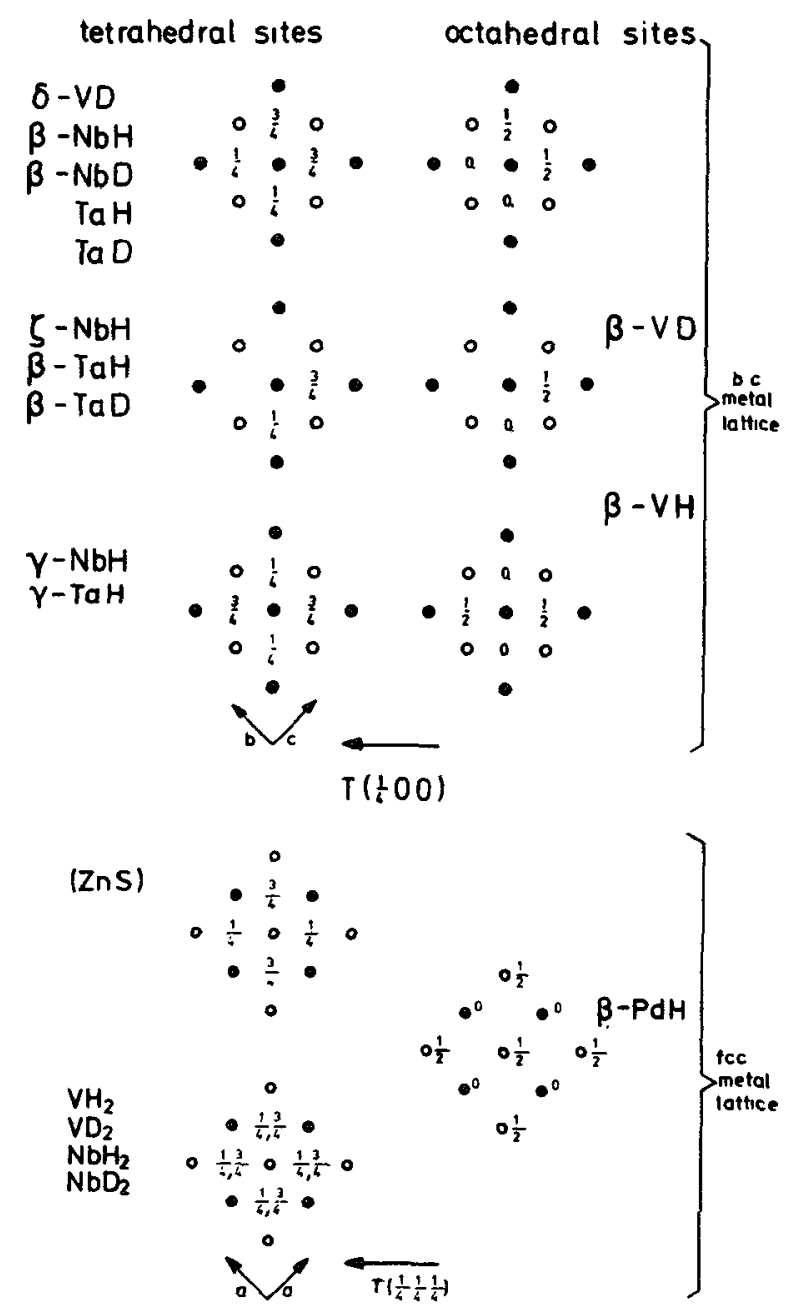

Fig. 1 : Projection of $\mathrm{H}$ ordering at tetrahedral or octahedral sites of bc or fcc metal lattices (open circles $\hat{\cong}$ at $x=0$, full circles $\hat{\equiv} M$ at $x=0.5)$.

mes large. Then the activation energy of diffusion usually has small values. The hydrides with small Coulomb interaction however, also have a lower thermal stability with small values for the free energy of formation $|\Delta G|$, which makes their investigation 


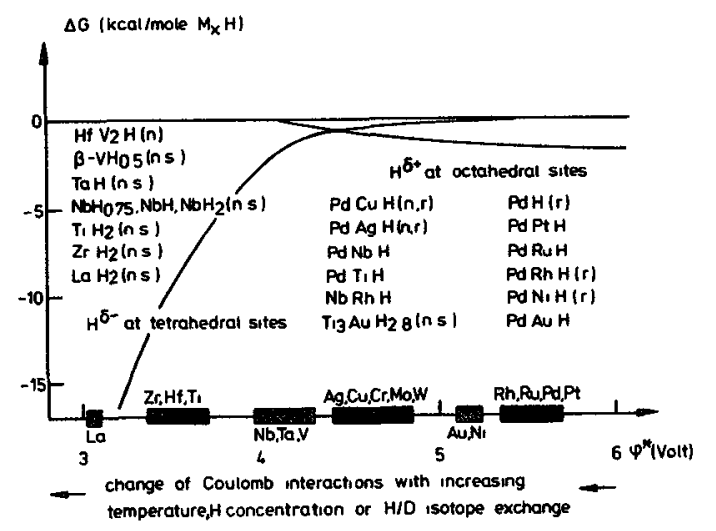

Fig. 2 : Free energy of hydride formation for transition metals with different electronegatives $\phi^{\mathrm{k}}$.

difficult.

It was outlined in former investigations, especially in the discussion of the isotope effect $16,7 /$, that a small force constant of $\mathrm{M}-\mathrm{H}$ bond is favourable for superconductivity. Ganguly/6/ considered similar electronic properties for PdH and PdD, whereas Miller and Satterthwaite/7/ also related different force constants to different electronic properties. Both however can not explain the puzzling behaviour of the hydrides : some show the normal isotope effect ( $n$ ) with a lower $T_{c}$ for the deuterated sample, other exhibit the reverse isotope effect ( $r$ ) with a higher $T_{c}$ or they even can change from normal to reverse with the composition of the alloy $(n, r) / 8 /$ (figure 2 ).

In the present model the different behaviour with normal or reverse isotope effect can be explained qualitatively. Thereby superconducting transition metal hydrides with strongly electronegative metals should show the reverse isotope effect, whereas those metals with an electronegativity smaller than $\sim 4.5 \mathrm{~V}$ (values of reference /5/) should behave normally (figure 2). Alloys usually have electronegativities intermediate between those of the pure components. $\mathrm{Th}_{4} \mathrm{H}_{15}$ apparently exhibits no detectable isotope effect/1/ because of the absence of crystal field effects. From figure 2 it also can be seen, that most transition metal hydrides with stronger Coulomb interactions are not superconducting (n.s.).

Because of the superconductivity of $\mathrm{V}$ with $T_{c}=5.3 \mathrm{~K}$ and the low crystal field stabilization of $\mathrm{V}$ hydrides, the $\mathrm{VH}$ and VD systems were reinvestigated. These hydrides and deuterides are also of particular interest for the determination of a structure dependency of superconductivity because of the different metal lattices and the different site occupancies of $H$ or $D$ (figure 1). So far low temperature $\mathrm{V}$ hydrides and deuterides with the following stoichiometries and site occupancies are known :

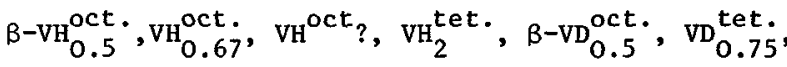
$\delta-\mathrm{VD}^{\text {tet. }}, \mathrm{VD}_{2}^{\text {tet. }}$

Samples with smal1 $\mathrm{H}$ or $\mathrm{D}$ content were prepared electrochemically in $\mathrm{H}_{3} \mathrm{PO}_{4}$ (or $\mathrm{D}_{3} \mathrm{PO}_{4}$, resp.) at $\sim 150^{\circ} \mathrm{C}$ using a current density of about $100 \mathrm{~mA} /$ $\mathrm{cm}^{2}$. Pure $\mathrm{VH}_{2}$ and $\mathrm{VD}_{2}$ could be obtained by continued mixing of $\mathrm{V}$ powder with $\mathrm{Zn}$ powder in dil. $\mathrm{HCl}$. Fcc VH ${ }_{2}\left(a=4.257 \AA\right.$ ) exhibits a $T_{c}$ (midpoint) of $3.9 \mathrm{~K} . \mathrm{VD}_{2}$ has a smaller room temperature lattice constant of $a=4.235 \AA$ because of the increased Coulomb interactions. $\mathrm{VD}_{2}$ and $\mathrm{all}$ the other $\mathrm{VH}_{\mathrm{x}}$ and $\mathrm{VD}_{\mathrm{x}}$ samples showed no superconducting transition above $1.5 \mathrm{~K}$.

ACKNOWLEDGEMENT. - The author wants to thank Dr. B.

N. Ganguly and Dr. B. Stritzker for very useful informations. The experimental help of B. Bischof, W. Bergs and F. Culetto is much appreciated.

\section{References}

11/ Satterthwaite,C.B. and Toepke,I.L., Phys. Rev. Lett. 25 (1970) 741

12/ Skoskiewicz,T., Phys. Status Solidi (a) 11 (1972) K123

/3/ Hauck,J. and Schenk,H.J., J. Less-Common Meta1s 51 (1977) 251

14/ Hauck, J., Proc. 2nd Int. Conf. Hydrogen in Metals, Paris 6 - 10 june 1977, Abstr. ID1

/5/ Miedema,A.R., Boom,R. and de Boer,F.R., J. LessCommon Metals 41 (1975) 283

/6/ Ganguly,B.N., Z. Phys. B22 (1975) 127

/7/ Miller,R.J. and Satterthwaite,C.B., Phys. Rev. Lett. 34 (1975) 144

/8/ Stritzker,B. and Wüh1,H., "Superconductivity in Meta1-Hydrogen Systems" in Topics in App1ied Physics (G. Alefer1,ed.) 1978 